\title{
The Entry Of International Banks In China
}

Yichen Wang, Renmin University, China

Régis Chenavaz, Kedge Business School, France

\begin{abstract}
With the remarkable degree of openness of China 's economy, an increasing number of foreign banks are rushing into this country. Two main theories prevail in current studies on the motivations offoreign banks to enter a new country, namely, customer-driven or market opportunity driven. Using the event study methodology, this paper analyses the value effect on foreign banks of the "entering the Chinese market" event. The results show that compared to customerdriven factors, the new opportunities of the Chinese market better explain this value effect. Our results provide a reference for foreign banks on operating strategies in China and enable a better understanding of the choice of destination and motivations forforeign banks to enter China.
\end{abstract}

Keywords: Foreign Bank, China, Customer-Driven, Market-Driven, Value Effect

\section{INTRODUCTION}

( ncreasing trade and financial globalization as well as the rapid economic development of China have attracted the interest of scholars in the Chinese banking industry (Cheng et al., 2013). Further, an increasing number of foreign financial organizations, especially foreign banks, have chosen to enter the Chinese market. In 1979, Export-Import Bank of Japan became the first foreign banking institution that established a representative office in China. Since then, a large number of foreign banks have followed suit. By the end of 2006, 14 wholly foreign owned and joint-venture banks registered in China, 74 foreign banks from 22 countries and regions opened 200 branches and 79 sub-branches in China, the total capital of domestic currency and foreign currency reached 103.3 billion dollars, deposits totalled 17.8 billion dollars with a total loan balance of 61.6 billion dollars. From 2006, all foreign banks could enter the Chinese mainland according to China's affirmation to the World Trade Organization (WTO). This was a good opportunity for foreign banks that intended to develop in the Chinese market. For first-movers, this led to fiercer industrial competition.

Why does the opening of the Chinese market create new value for foreign banks? Academic circles summarize the studies of transnational bank operations in terms of customer follower theory, market development theory and first mover follower theory. Customer follower theory argues that given the general trade and financial globalization, banks tend to follow customers to maintain their stable customer stock. That is to say, when major customers enter a foreign market, banks will follow these customers into the target market to avoid losing customers. Market development theory argues that a new beneficial market is the main reason for attracting banks. Differing from the previous strategy, banks will explore new customers in the new market. The first-mover follower theory argues that banks will follow industrial leaders or major competitors into foreign markets to maintain their competitive position. This last theory has limited research significance in relation to the host country and this paper aims to establish which of the first two theories can explain the value effect of foreign banks expanding into China.

Nearly 50 foreign banks have entered China through establishing representative offices, branches or subsidiaries in the last two decades, while nearly 30 banks have established wholly owned subsidiaries in China. These banks are similar in terms of capital scale, area distribution and business characteristics, yet differ in other aspects thereby providing abundant material for our study. We selected 17 representative banks ${ }^{1}$ to analyse the short-term market response of 19 subsidiaries in China from an event study perspective. The research shows that market opportunities in China could better explain the value effect of foreign banks establishing subsidiaries in China.

${ }^{1}$ Deut sche Bank and Standard Chartered Bank were listed in multiple exchanges.

Copyright by author(s); CC-BY 


\section{LITERATURE REVIEW AND RESEARCH HYPOTHESIS}

\section{Customer Follower}

Customer follower theory originated from the Defensive Expansion Hypothesis that Krause et al. (1975) proposed. This hypothesis argues that banks choose to enter a host country to maintain their long-term relationships with old customers. Compared to prior theoretical explanations, the breakthrough of this theory was in easily being supported by empirical research and reasonable in explaining the economic factors of foreign banks, since the customer scale and quality of these banks/financial service departments could reflect their competitiveness. Scholars Miller and Parkhe (1998) researched the operations of American banks in 32 countries and regions from 1987 to 1995 and found a significant correlation between foreign direct investments and degree of entry of foreign banks. Furthermore, Esperance and Gulamhussen (2001) show that the customer groups that banks follow do not only comprise companies and institutions, but also emigrants and long-term residents.

In the customer follower theory perspective, as China frequently trades with other countries and has opened up to the whole world, a growing number of customers invest in or take up residence in China and profit from providing financial services to their original customers from the home country, which may help them explore their growth potential, provide new value growth space and realize the value effect.

\section{Market Development}

Academic circles study market development theory from different perspectives, but largely consider specific home country factors. The findings of Fozzolo and Focarelli (2000) are widely used. These authors use a sample of 143 banks that established branches in 28 countries and regions to study the economic growth expectation factors, the bank subsidiary access mechanis ms and the competitiveness of the host country. They find that foreign banks tend to have stronger motives to enter the market when the host country's banking systemis less efficient but has good economic prospects. The results not only show that foreign banks prefer to enter host countries with greater economic growth potential, but also that the low efficiency of banks in host countries (higher cost, lower net interest margin) attracts more foreign banks. In addition, Claessens, Demirguc-Kunt and Huizinga (2001) find that host country markets with higher income and lower tax may attract more foreign banks.

The research is more representative when China is the theoretical research objective. First, China has bettereconomic development prospects and ranks top in economic volume and speed of growth. Further, the Chinese financial system, particularly the banking system, is still transiting to a complete market-oriented economic systemand their efficiency is thus likely to increase. In summary, China is a new market with a bright future.

Foreign banks would therefore benefit from taking advantage of their management experience and HR allocation to expand their business and explore new customers in China, thereby realizing the value effect.

\section{Other Perspectives}

Aside from the two aforementioned theories, some scholars explain foreign banks from different perspectives. Li (2008) analyses enterprise management and argues that enterprises tend to use two operational decision models. The first is the response decision to confront emergent changes in the environment, called "stimulation-response motive", the second is the active decision according to their resources and development strategies, called the "resource-inner motive". The former is considered a mature motive or the leading motive when banks enter a similar market. Foreign banks as rational decision-makers will make some defensive decisions to maintain their comparative competitiveness under a changing external environment, including competition following, customer following and control avoidance. The latter is considered a threshold motive or when banks enter a brand new market, arguing th at in the home country the market environment has no potential and therefore expanding in other markets.

In addition to the theoretical studies, some scholars analyse the entry strategies of foreign banks from the empirical research pers pective under different time and space conditions. Zhu and $\mathrm{Xu}$ (2007) maintain that foreign banks tend to have different motives when entering developed and developing countries. For developing countries, foreign banks 
consider that the new economic entity could lead to new economic growth and that the characteris tics of host countries are attractive and therefore customer follower theory is not applicable. The research results support this view to some degree. Xue (2011) empirically analyses the different entry motives of foreign banks in China from 1985 to 2009 , finding that from 1985 to 1996 customer following constituted the main factor for these foreign banks to serve their home country customers in China. From 1997 to 2009, the leading factor was instead market opportunity, whereby foreign banks focused more on seizing Chinese market opportunities.

\section{EMPIRICAL ANALYSIS}

\section{Sample Description}

Foreign banks tend to take many different forms when entering a country. The present paper argues that building a wholly owned subsidiary in host countries is the most complete and comprehensive form and that host countries have important strategic significance for foreign banks. We therefore consider this form in our sample selection. Due to the absence of data on some banks, we selected 17 representative foreign banks that have established wholly owned subsidiaries in China. Table 1 provides the description of our sample:

Table 1. Sample description

\begin{tabular}{|c|c|c|c|}
\hline Bank & Headquarters & $\begin{array}{c}\text { Time and way of doing business in } \\
\text { mainland China }\end{array}$ & Subsidiary company ${ }^{2}$ \\
\hline UBS & Switzerland & $\begin{array}{l}\text { Issuing the first European dollar bond for } \\
\text { Chinese banks in } 1987\end{array}$ & $\begin{array}{l}\text { UBS (China) Ltd was founded in Beijing in } \\
2012\end{array}$ \\
\hline Metrobank & Philippine & $\begin{array}{l}\text { The representative office was established } \\
\text { in Shanghai in } 1992\end{array}$ & $\begin{array}{l}\text { Metrobank (China) Ltd was founded in Nanjing } \\
\text { in } 2010\end{array}$ \\
\hline $\begin{array}{l}\text { East West } \\
\text { Bank }\end{array}$ & USA & - & $\begin{array}{l}\text { East West Bank (China) Ltd was founded in } \\
\text { Shanghai in } 2010\end{array}$ \\
\hline $\begin{array}{l}\text { Deutsche } \\
\text { Bank }\end{array}$ & Germany & $\begin{array}{l}\text { The agent office was established } \\
\text { Shanghai in } 1872\end{array}$ & $\begin{array}{l}\text { Deutsche Bank (China) Ltd was founded in } \\
2008\end{array}$ \\
\hline $\begin{array}{l}\text { Societe } \\
\text { Generale }\end{array}$ & France & $\begin{array}{l}\text { The representative office was established } \\
\text { in Beijing in } 1981\end{array}$ & $\begin{array}{l}\text { Societe Generale (China) Ltd was founded in } \\
2008\end{array}$ \\
\hline Dahsing Bank & Hong Kong & - & $\begin{array}{l}\text { Dahsing Bank (China) Ltd was founded in } \\
\text { Shenzhen in } 2008\end{array}$ \\
\hline BEA & Hong Kong & $\begin{array}{l}\text { A branch was established in Shanghai in } \\
1920\end{array}$ & $\begin{array}{l}\text { BEA (China) Ltd was founded in Shanghai in } \\
2007\end{array}$ \\
\hline J. P. Morgan & USA & $\begin{array}{l}\text { Became the Huguang railway bond } \\
\text { underwriter in } 1911\end{array}$ & J. P. Morgan (China) Ltd was founded in 2007 \\
\hline $\begin{array}{l}\text { Wing Hang } \\
\text { Bank }\end{array}$ & Hong Kong & $\begin{array}{l}\text { The branch was founded in Guangzhou } \\
\text { in } 1937\end{array}$ & $\begin{array}{l}\text { Wing Hang Bank (China) Ltd was founded in } \\
\text { Shenzhen in } 2007\end{array}$ \\
\hline $\begin{array}{l}\text { Hang Seng } \\
\text { Bank }\end{array}$ & Hong Kong & $\begin{array}{l}\text { The representative office was established } \\
\text { in Shenzhen in } 1985\end{array}$ & $\begin{array}{l}\text { Hang Seng Bank (China) Ltd was founded in } \\
\text { Shanghai in } 2007\end{array}$ \\
\hline HSBC & Hong Kong & HSBC was founded in Shanghai in 1865 & $\begin{array}{l}\text { HSBC (China) Ltd was founded in Shanghai in } \\
2007\end{array}$ \\
\hline $\begin{array}{l}\text { Standard } \\
\text { Charted Bank }\end{array}$ & UK & $\begin{array}{l}\text { A branch was established in Shanghai in } \\
1858\end{array}$ & $\begin{array}{l}\text { Standard Charted Bank (China) Ltd was } \\
\text { founded in } 2007\end{array}$ \\
\hline $\begin{array}{l}\text { Morgan } \\
\text { Stanley }\end{array}$ & USA & $\begin{array}{l}\text { The representative office was established } \\
\text { in Shanghai in } 1994\end{array}$ & $\begin{array}{l}\text { Morgan Stanley (China) Ltd was founded in } \\
2006\end{array}$ \\
\hline BNP Paribas & France & $\begin{array}{l}\text { The representative office was established } \\
\text { in Shanghai in } 1860\end{array}$ & $\begin{array}{l}\text { BNP Paribas (China) Ltd was founded in } \\
\text { Shanghai in } 2003\end{array}$ \\
\hline SMBC & Japan & $\begin{array}{l}\text { The representative office was established } \\
\text { in Beijing in } 1982\end{array}$ & SMBC (China) Ltd was founded in 2009 \\
\hline Citibank & USA & $\begin{array}{l}\text { The branch was established in Shanghai } \\
\text { in } 1902\end{array}$ & Citibank (China) Ltd was founded in 2007 \\
\hline $\mathrm{BMO}$ & Canada & $\begin{array}{l}\text { Established an agency relationship with } \\
\text { Chinese banks in } 1962\end{array}$ & BMO (China) Ltd was founded in 2010 \\
\hline
\end{tabular}

\footnotetext{
${ }^{2}$ Establishment here is the opening of the official website of these banks, which differs from the date of the specific events mentioned later. Copyright by author(s); $\underline{\text { CC-B Y }}$ 
These samples derive from nine countries and regions, most with developed economies. Due to the regional differences, the samples provide rich levels of data with the following characteristics. First, these banks entered the Chinese market in recent years, some providing financial services for the government, some entering China by establishing a representative office or branch in the 1980s. Although entering China in different periods, these banks have traded in China for numerous years and have accumulated rich experience in the Chinese market. Second, from the operating scope perspective, these samples not only include international banks such as Morgan Stanley and Citibank, but also regional banks such as Wing Hang Bank, Metrobank and SMBC. While these regional banks are not as competitive as international banks in terms of capital volume or international influence, most are large banks with a significant market share and operating strength in the region. Third, all samples are listed companies, some on two stock exchanges. These samples are mature entities and normalized in terms of information transparency and enterprise management, which enabled collecting the effective market response data.

\section{Specification of Variables}

The event study observes whether there is an abnormal return in the sample share price when the event occurs and explains the influences of the special event on the sample share price based on the effective market hypothesis. To control for the influence of other events on share price, we consider as the special event when the sample banks established a subsidiary in China. The special event date is the date when the China Banking Regulatory Commission (CBRC) issued the official document of the bank's application to establish a subsidiary. The event window is the week before and after and the event ( \pm 5 trading days). According to the share price data of the sample banks, we calculate the actual rate of return of the share price of these sample banks ${ }^{3}$ with $R_{i}=\left(P_{i, n+1} p_{i, n-1}\right) / P_{i, n-1}$. Thereafter, we calculate the ordinary rate of return according to the overall bank share price in the event window ${ }^{4}$ as $R_{m}=$ $\left(P_{m, n+1} p_{m, n-1}\right) / P_{m, n-1}$. Finally, we calculate the difference between the actual rate of return and the ordinary ov erall rate of return and obtain the rate of abnormal return $A b_{\text {ret }}=R_{i} R_{m}$.

To explore whether foreign banks enter China to follow and serve their original customers in the home country, we chose two indexes as the explanatory variables. The first is total volume of bilateral trade between the home country and China (Bi-TV). According to He and Wang (2007), the customer follower effect of foreign banks is significantly and positively correlated with the economic relationship between the home country and host country. The volume of bilateral trade is a key index that measures the economic relationship between two countries and is included in the interpretation model. The second index is the net inflow of foreign direct investments (FDI). We argue that a description of the degree of circulation of goods between two countries alone is insufficient and therefore select this variable to measure the economic relationship between China and other countries in a capital circulation perspective. The Bi-TV date derives from the Ministry of Commerce of the People's Republic of China data centre ${ }^{5}$ while the FDI data derives comes from the World Bank database ${ }^{6}$.

To study whether Chinese market opportunities can lead to new value growth for foreign banks, we selected two explanatory variables: Chinese GDP growth rate (GDP-GR) and the one-year loan-deposit interest rate margin (IRM). According to prior studies, a country's economic prospect and bank operating efficiency are key factors in foreign bank entry. As key indexes that measure a country's economic development and the total operating efficiency of banks, GDP-GR and IRM should therefore be included in the model. We measure Chinese market opportunities using these two indexes, the former from the World $\mathrm{Bank}^{7}$ database and the latter from the Statistics and Analysis Department of The People's Bank of China database ${ }^{8}$.

\footnotetext{
${ }^{3}$ Data source of stock price: http://finance.y ahoo.com

${ }^{4}$ Data source of the whole bank industry: http://finance.yahoo.com

${ }^{5}$ Data source : http://data.mofcom.gov.cn

${ }^{6}$ Data source : http://data. worldbank.org.cn/indicator/BX.KLT.DINV.CD.WD

${ }^{7}$ Data source : http://data. worldbank.org.cn/indicator/BX.KLT.DINV.CD.WD

${ }^{8}$ Data source : http://www.pbc.gov.cn/publish/diaochatongjisi/126/index.html 


\section{Descriptive Statistics}

Table 2 shows the observation results of the 5 variables for our 19 samples.

Table 2. Observed values

\begin{tabular}{|c|c|c|c|c|c|c|}
\hline \multirow{2}{*}{ Bank } & \multirow{2}{*}{ Date of event ${ }^{9}$} & \multirow{2}{*}{ Ab_ret $(\%)$} & \multicolumn{2}{|c|}{ Chinese market factors } & \multicolumn{2}{|c|}{$\begin{array}{l}\text { Customer factors of the home } \\
\text { country }\end{array}$} \\
\hline & & & $\begin{array}{c}\text { GDP_GR } \\
(\%)\end{array}$ & IRM (\%) & $\begin{array}{c}\text { FDI } \\
\text { (billion dollars) }\end{array}$ & $\begin{array}{c}\text { Bi_TV } \\
\text { (10 billion dollars) }\end{array}$ \\
\hline UBS & 05.01 .2011 & 3.00 & 10.30 & 3.06 & 27.30 & 47.97 \\
\hline Metrobank & 31.12 .2009 & 3.36 & 10.29 & 3.06 & 16.71 & 2.05 \\
\hline East West Bank & 31.08 .2010 & 1.82 & 10.30 & 3.06 & 27.30 & 38.53 \\
\hline \multirow{2}{*}{ Deutsche Bank $^{10}$} & \multirow{2}{*}{ 05.07.2007 } & 1.28 & 10.51 & 3.30 & 16.94 & 9.41 \\
\hline & & -0.86 & 10.51 & 3.30 & 16.94 & 9.41 \\
\hline Societe Generale & 04.08 .2008 & 8.45 & 10.41 & 3.06 & 18.68 & 5.85 \\
\hline Dashing Bank & 05.12 .2008 & -1.75 & 10.41 & 3.06 & 18.68 & 20.37 \\
\hline BEA & 22.12 .2006 & -0.96 & 9.99 & 3.60 & 13.33 & 16.62 \\
\hline J. P. Morgan & 11.10 .2007 & 1.24 & 10.51 & 3.30 & 16.94 & 30.21 \\
\hline Wing Hang Bank & 31.01 .2007 & 4.09 & 9.99 & 3.60 & 13.33 & 16.62 \\
\hline Hang Seng Bank & 22.12 .2006 & -2.82 & 9.99 & 3.60 & 13.33 & 16.62 \\
\hline HSBC & 02.04 .2007 & 2.90 & 9.99 & 3.60 & 13.33 & 19.73 \\
\hline \multirow{2}{*}{ Standard Charted Bank } & \multirow{2}{*}{ 20.03.2007 } & 0.18 & 9.99 & 3.60 & 13.33 & 4.28 \\
\hline & & 2.14 & 9.99 & 3.60 & 13.33 & 4.28 \\
\hline Morgan Stanley & 29.09 .2006 & 1.20 & 9.99 & 3.60 & 13.33 & 26.27 \\
\hline BNP Paribas & 26.11 .2003 & 1.55 & 8.95 & 3.30 & 4.95 & 1.34 \\
\hline SMBC & 27.04.2009 & 15.74 & 10.41 & 3.06 & 18.68 & 22.89 \\
\hline Citibank & 22.12 .2006 & 0.53 & 9.99 & 3.60 & 13.33 & 26.27 \\
\hline $\mathrm{BMO}$ & 24.07.2009 & 2.25 & 10.29 & 3.06 & 16.71 & 2.97 \\
\hline
\end{tabular}

Following the rate of abnormal return calculated above, we now explain the operationalization of our other 4 variables:

1. GDP-GR: These sample banks established a subsidiary in China around 2000. To reflect the attribute "foreign bank prediction of Chinese economic prospect", we take the average annual GDP growth rate from 2000 to the year when the bank established the subsidiary as the observed value of the variable. We argue that this is more representative than GDP growth rate in the year when the subsidiary was established, as reflected by our more effective regression results.

2. IRM: The observed value here is the recent interest rate margin of a one-year loan-deposit after adjustment before the specific event occurred since the Central Bank interest rate is universal.

3. FDI: As our sample banks come from different countries and regions, the total inflow of foreign direct investments in the year when the specific event occurred is taken as the observed value.

4. Bi-TV: For information on investordecisions, when the specific event occurred before June, we use the bilateral trade volume one year before as the observed value; when the event occurred after June, we use the data in that year as the observed value.

Table 3 provides the descriptive statistics of these 5 variables.

\footnotetext{
${ }^{9}$ This refers to the date when the event occurred.

${ }^{10}$ We have two values here as the bank went public in two stock markets in different countries, the same applies to Standard Chartered Bank.
} 
Table 3. Descriptive statistics

\begin{tabular}{l|c|c|c|c|c|c}
\hline \multicolumn{1}{c|}{ Variable } & $\begin{array}{c}\text { Number of } \\
\text { samples }\end{array}$ & Mean value & Median & $\begin{array}{c}\text { Standard } \\
\text { deviation }\end{array}$ & $\begin{array}{c}\text { Maximum } \\
\text { value }\end{array}$ & $\begin{array}{c}\text { Minimum } \\
\text { value }\end{array}$ \\
\hline $\mathrm{Ab}$ _ret & 19 & 2.28 & 1.15 & 4.07 & 15.74 & -2.82 \\
\hline $\mathrm{Bi}$ TV & 19 & 16.93 & 16.62 & 13.02 & 47.97 & 1.34 \\
\hline FDI & 19 & 16.13 & 16.71 & 5.05 & 27.30 & 4.95 \\
\hline GDP_GR & 19 & 10.15 & 10.29 & 0.36 & 10.51 & 8.95 \\
\hline IRM & 19 & 3.34 & 3.30 & 0.25 & 3.60 & 3.06 \\
\hline
\end{tabular}

According to these result, the average value of $\mathrm{Ab}$-ret is $2.28 \%$, the standard deviation is 4.07 , the maximu $\mathrm{m}$ value is $15.74 \%$ of SMBC and the minimum value is $-2.82 \%$ for Hang Seng Bank, which may show that different investors respond differently to the event of foreign banks establishing a subsidiary in China. In addition, we find that some variables fluctuate sharply due to the small sample size, which we discuss later.

\section{RESULTS}

To test the value effect of customer following and market opportunity on the event of foreign banks establishing a subsidiary in China, we constructed the following regression model:

$$
A b_{\text {ret }}=\alpha+\beta_{1} B i_{T V}+\beta_{2} F D I+\beta_{3} G D P_{G R}+\beta_{4} I R M
$$

where:

Ab-ret: Abnormal return rate of share price

Bi-TV: Total volume of bilateral trade in the specific year

FDI: Net inflow of foreign direct investments

GDP-GR: Average annual growth rate of Chinese GDP

IRM: Interest rate margin of the one-year loan-deposit in China in the specific year

We conduct three regression analyses. In the first, Bi-TV, FID, GDP-GR and IRM are the explanatory variables in the model and the results are shown in Tables 4 to 6:

Table 4. Model 1 - All Factors

\begin{tabular}{l|l|l|l|l|l}
\hline \multirow{2}{*}{$\begin{array}{l}\text { F=0.755 } \\
\text { Sig=0.571 }\end{array}$} & \multicolumn{2}{|c|}{ Non-standardized coefficients } & \multirow{2}{*}{$\begin{array}{c}\text { Standardized } \\
\text { coefficients }\end{array}$} & \multirow{2}{*}{ Sig } & \multirow{2}{*}{ VIF } \\
\cline { 2 - 3 } & \multicolumn{1}{|c|}{ S tandard error } & & 0.669 & \\
\hline Constants & 18.215 & 41.762 & & 0.774 & 2.622 \\
\hline Bi_TV & 0.36 & 0.123 & 0.115 & 0.660 & 6.676 \\
\hline FDI & -0.227 & 0.505 & -0.281 & 0.732 & 2.474 \\
\hline GDP_GR & 1.506 & 4.308 & 0.133 & 0.183 & 2.271 \\
\hline IRM & -8.437 & 6.029 & -0.551 & & \\
\hline
\end{tabular}

All coefficients in the regression analys is fail to pass the significance test under the $10 \%$ level, the explanation effect of the model on Ab-ret is generally low and the model is hence unsatisfactory. However, as our intention is not to explain Ab-ret but find a way to better explain the Ab-ret between the market opportunity factor and the customer following factor, strong significance of the model is not required.

To compare these two factors, we use the market opportunity indexes (GDP-GR and IRM) as the explanatory variables and eliminate the customerfollowing factors (Bi-TV and FDI) in oursecond regression analysis. The regression results are shown in Table 5. 
Table 5. Model 2 - Market Opportunity

\begin{tabular}{|c|c|c|c|c|c|}
\hline \multirow{2}{*}{$\begin{array}{l}F=1.584 \\
\text { Sig }=0.236\end{array}$} & \multicolumn{2}{|c|}{ Non-standardized coefficients } & \multirow{2}{*}{$\begin{array}{l}\text { Standardized } \\
\text { coefficients }\end{array}$} & \multirow{2}{*}{ Sig } & \multirow{2}{*}{ VIF } \\
\hline & B & Standard error & & & \\
\hline Constants & 23.101 & 37.806 & & 0.550 & \\
\hline GDP_GR & 0.127 & 2.889 & 0.11 & 0.965 & 1.253 \\
\hline IRM & -6.625 & 4.220 & -0.401 & 0.136 & 1.253 \\
\hline
\end{tabular}

Generally, the regression analys is is not significant and the model lacks explanatory power. However, worth noting is that models 1 and 2 show no significant difference in the explanatory effect. Finally, we eliminate the market opportunity factors (GDP-GR and IRM) and use the customer following factors (Bi-TV and FDI) for our third regression analysis. The regression results are shown in Table 6.

Table 6. Model 3 - Customer Following

\begin{tabular}{l|c|c|c|c|c}
\hline \multirow{2}{*}{$=0.532$} & Non-standardized coefficients & Standardized & \multirow{2}{*}{ Sig } & \multirow{2}{*}{ VIF } \\
\cline { 2 - 3 } Sig=0.598 & B & Standard error & & 0.779 & \\
\hline Constants & -0.976 & 3.421 & 0.321 & 0.321 & 1.680 \\
\hline FDI & 0.259 & 0.253 & -0.174 & 0.587 & 1.680 \\
\hline Bi_TV & -0.054 & 0.098 & & \\
\hline
\end{tabular}

The regression model is not very significant and still fails to give effective explanations for Ab-ret. However, we find that model 3 greatly differs from models 1 and 2 in explanatory power, which can answer our question from another perspective.

From these tests, we as sume that the non-significance of the models may be related to the following reasons:

1. Small sample size

2. The actual factors influencing share price fluctuations are complex; other factors such as favourable or unfavourable influences, transaction system differences, speculation factors and the irrational operation of investors are not effectively controlled for.

To solve the problem that market share may not always reflect the value of companies, we obtained operating performance data after the banks established a subsidiary in China and observed the actual performance of foreign banks in a post analysis perspective. We use the core financial data indexes of our 17 sample banks to observe their total capital, net income, net rate of interest income and average return rate. The observation results are presented in the following Figures 1 to $4^{11}$.

\footnotetext{
${ }^{11}$ Data source: Analysis Database of BankScope Global Bank and Financial Organization https://bankscope.bvdinfo.com/version-2015420/home.serv?product=scope2006 
Figure 1. Total Assets

\section{Total Asset(Million Dollars)}

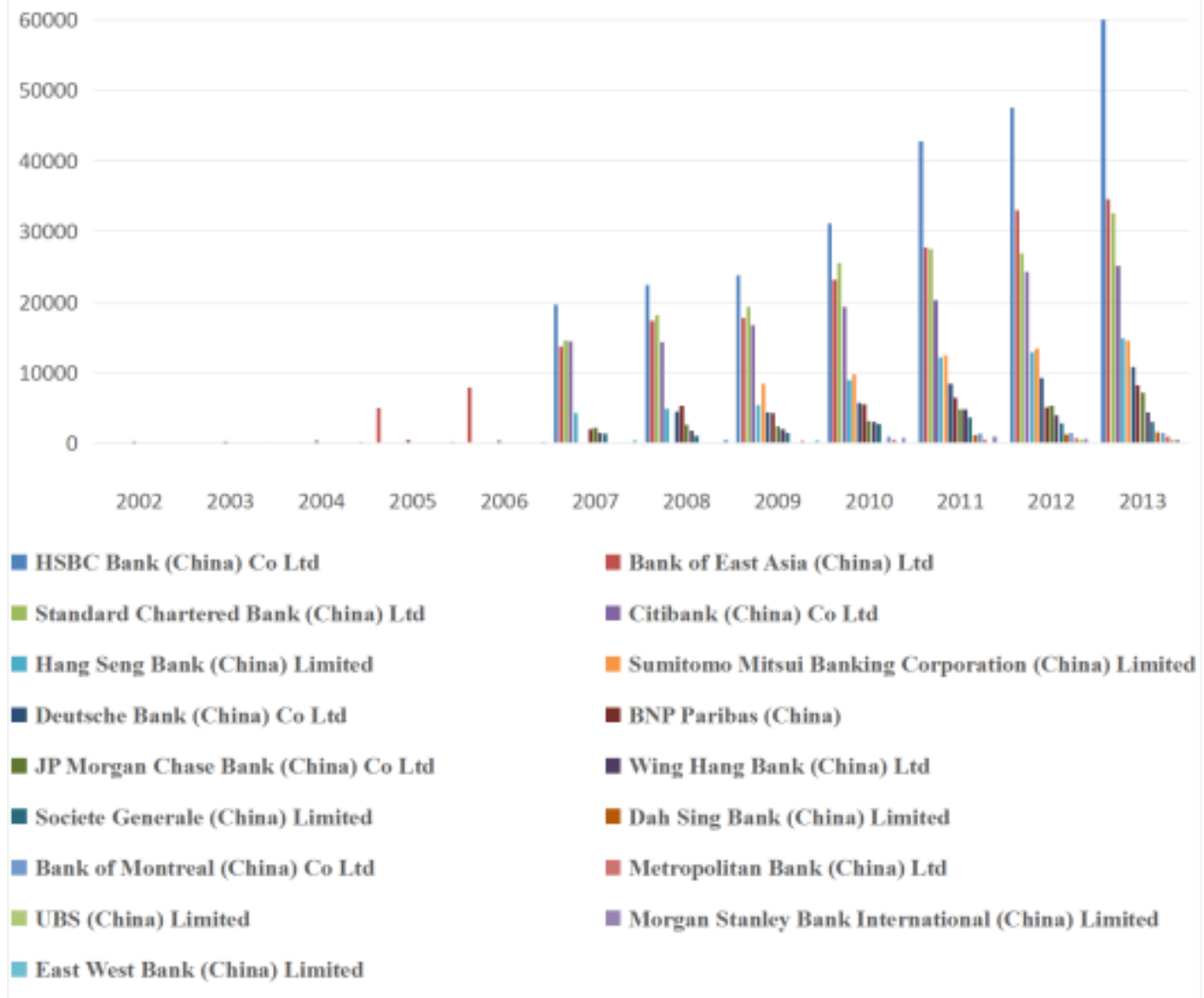

Generally, the capital volume of most Chinese subsidiaries of these foreign banks increased. HSBC China ranks first in the list with a total capital of 59.9 billion dollars up to 2013, nearly twice that of BEA. It also ranks first in terms of capital expansion speed. However, SMBC, which ranks first in the abnormal rate of return is ranked 6th in capital expansion speed, which fails to reflect its outstanding capital growth capacity. 
Figure 2. Net income

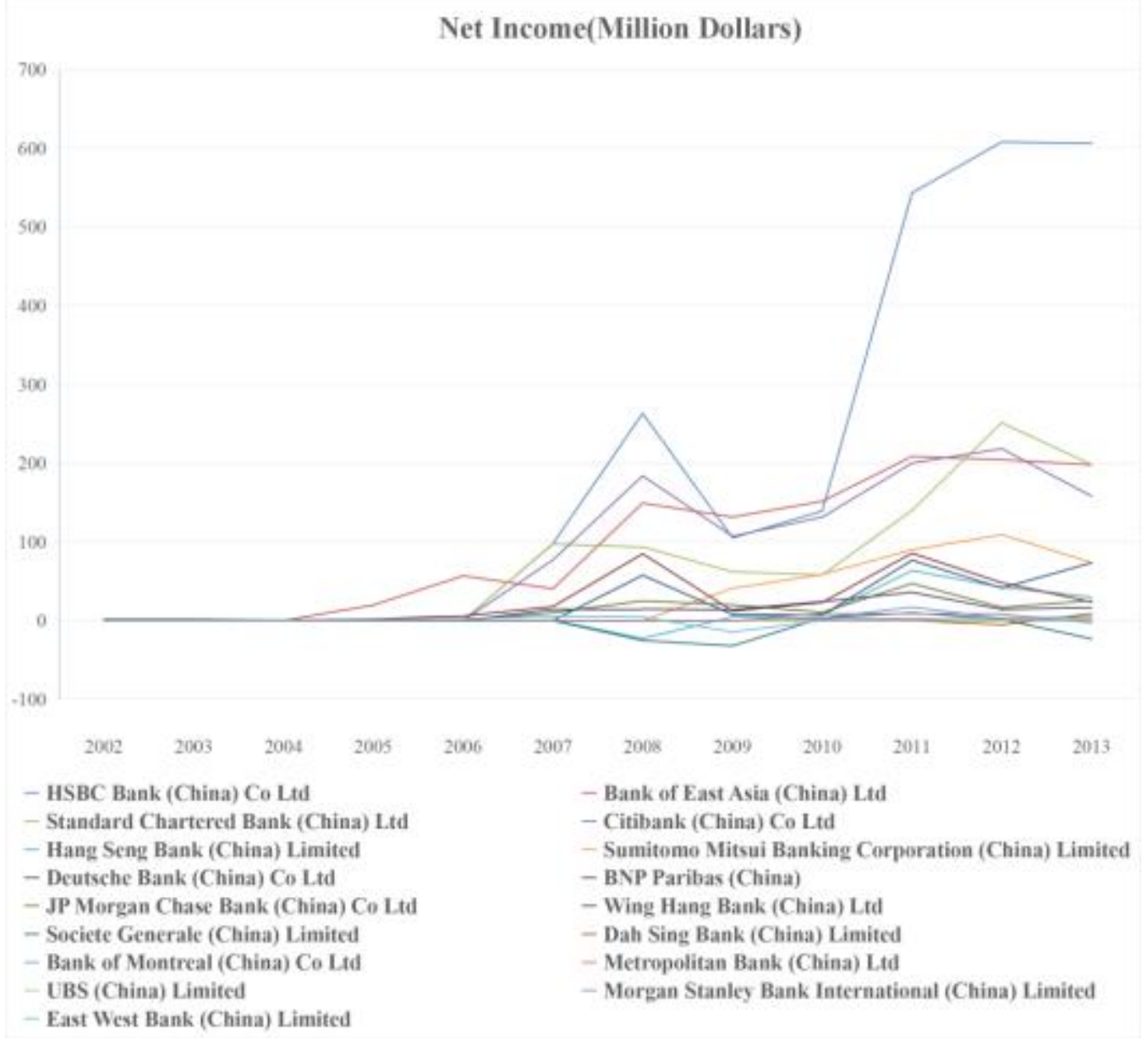

In 2013, the net income of HSBC China was 606 million dollars. The bank ranks first in this item for the subsequent three years, increasing 290\% in 2010. Standard Charted Bank China ranks 2nd in the item in 2010 and SMBC ranks 5th. From the general growth rate perspective, there is no doubt that HSBC grew fastest among these foreign banks followed by Standard Chartered Bank, BEA and Citibank. Worth noting is that the net income declined in most foreign banks in 2012, although Deutsche Bank maintained a stable growth rate. 
Figure 3. Net interest income rate

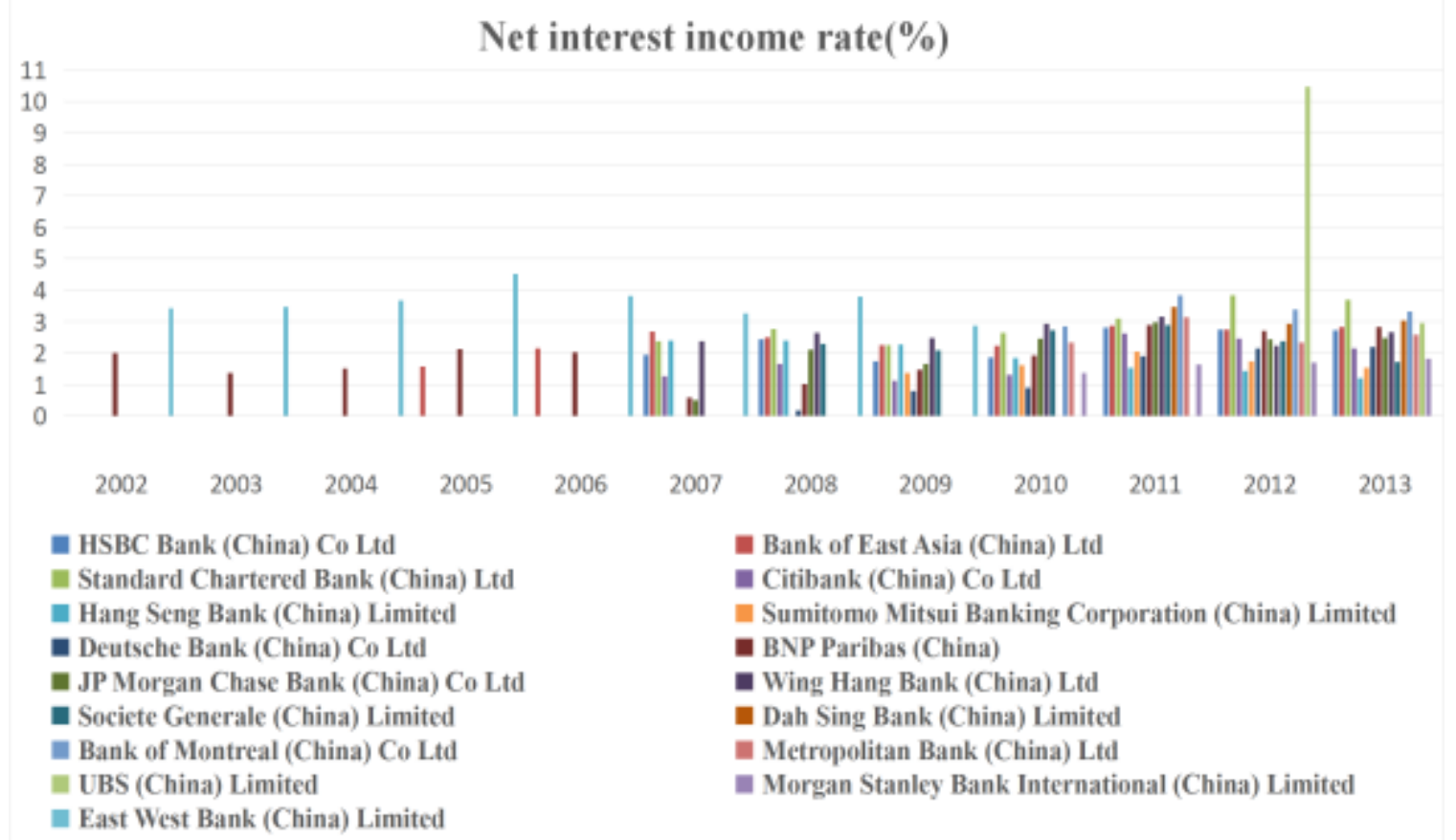

The overall interest income is around 2.4\%. In 2012, SBC ranked first with $10.45 \%$ of net interest income rate in the first year when its subsidiary was founded in China. The bank ranked top in this item in 2013. SMBC's interest income rate was $1.53 \%$ in the same year.

Figure 4. Average ROA

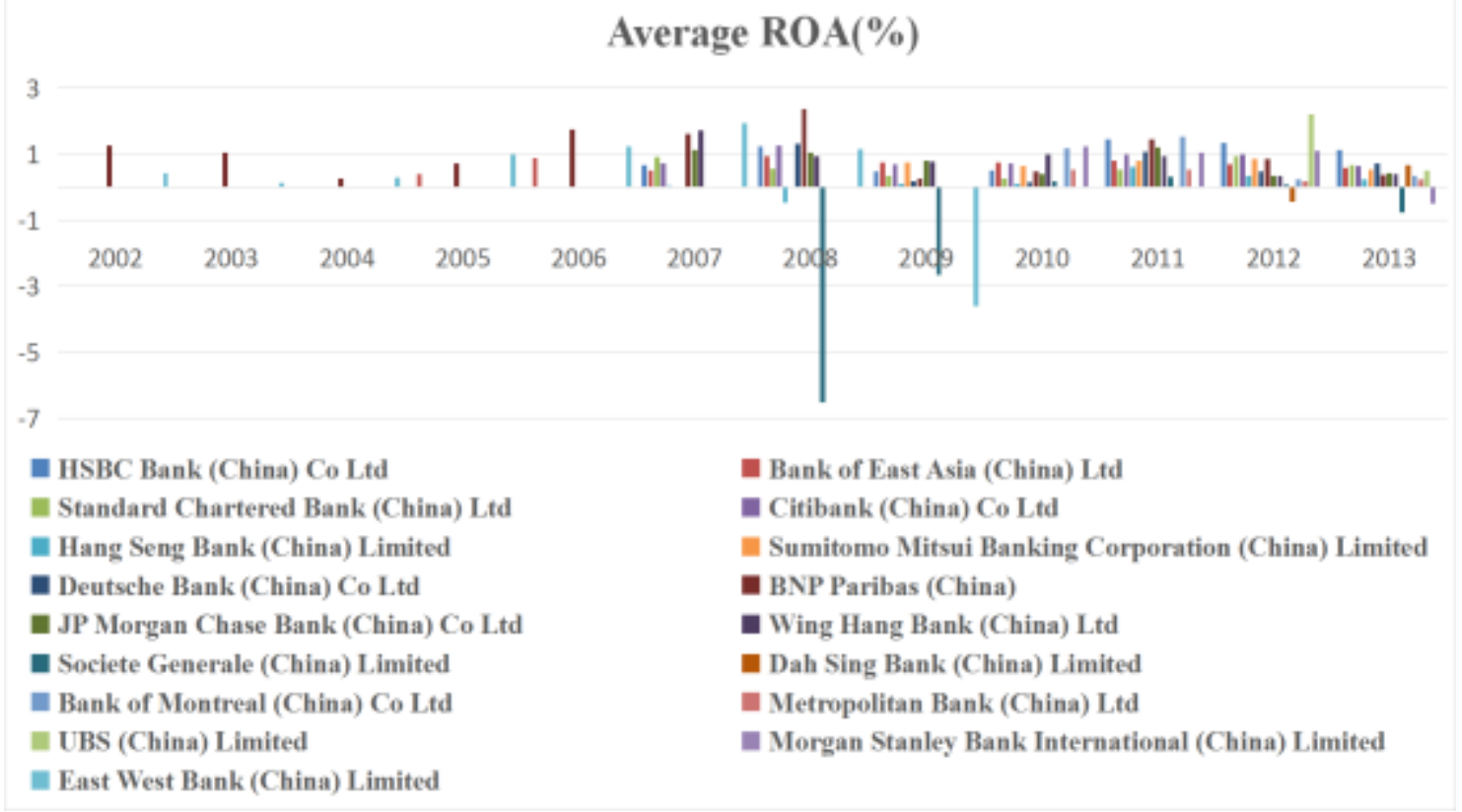


Generally, the average annual ROA of most of the foreign banks is around $0.6 \%$ except Societe Generale with a negative ROA in 2008 and 2009, and East West Bank with a negative ROA in 2009. The average ROA of Societe Generale ranks top before 2008 and its highest ROA reached 2.36\%. However, its ROA began to decline due to the financial crisis. According to the 2013 data, HSBC ranked first with $1.11 \%$ of ROA, Deutsche Bank second with $0.73 \%$ of ROA and SMBC 7 th with $0.52 \%$ of ROA.

From observing these four core indexes, we find that most of the subsidiaries of these foreign banks developed quickly in China and attained considerable asset volumes and profit levels in the Chinese market. In addition, we find that share price may at times not reflect the real value of the companies and the value effect may thus not be comprehensive. We observe that SMBC, with the highest abnormal rate of return is not the most competitive foreign bank in China. The share price deviates from the operating result. However, share price fluctuation matches post operating performance in many banks including SBC, HSBC and BOM.

\section{CONCLUSION}

We selected and analysed the event of 19 representative foreign banks establishing a subsidiary in China to test the effect of market opportunity factors and customer following factors on the value effect. Although the regression results show that the models and coefficients are not significant, we draw the conclusion that after comparing the explanatory degree of the Ab-ret of these 3 regression models, Chinese market opportunity factors better explain the value effect of foreign banks expanding in the Chinese market than the customer follower factors in the home country.

From a foreign bank development perspective, China is a country with great economic growth potential and a key market to expand their businesses. An increasing number of high-quality customers in China have considerable business value for these foreign banks. For China, international operations, mature management models and financial technology innovation will in turn accompany the entry of foreign banks. Alongside improving market compet ition in Chinese banks, external competition will promote the development of domestic banking efficiency. Our analysis contributes by providing a reference framework for foreign banks on entering and expanding their business in China while providing a reference framework for China on foreign bank entry, improving the investment environment, and attracting a great number of outstanding investors.

\section{AUTHOR BIOGRAPHIES}

Yichen Wang is a graduate student in financial studies at Renmin University. He is interested in finance and banking with a strong emphasis on international and Chinese issues.E-mail: yichen.wang02@kedgebs.com

Régis Chenavaz is Assistant Professor of Economics at Kedge Business School and researcher at Aix-Marseille School of Economics, CNRS and EHESS. He conducts research on firm policies.

E-mail: regis.chenavaz@kedgebs.com

\section{REFERENCES}

Cheng, M., Zhao, H., \& Zhang, J. (2013). The Effects of Ownership Structure and Listed Status on Bank Risk in China. Journal of Applied Business Research, 29(3), 695-710.

Claessens, Stijn, Aslı Demirgüç-Kunt, and Harry Huizinga. (2001) How does foreign entry affect domestic banking markets?, Journal of Banking \& Finance 25(5), 891-911.

He, D., \& Wang, C. (2007). Motives, Forms, and Influences of Entry of Foreign Banks. Contemporary Finance and Economics, 1

Esperance, J.P., \& Gaulamhussen, M.A.(2001). (Re)Testing the "Follow the Customers Hypothesis" in Multinational Bank Expansion. Journal of Multination Financial Management, 11(3): 281-293.

Krause, Lawrence B., Andrew F.. Brimmer, and Frederick R. Dahl (1975) Growth of American international banking: implications for public policy, The Journal of Finance 30(2), 341-363.

Li, J. (2008). Entry and Handling Strategy Choice of Foreign Banks [J]. Inquiry into Economic Issues, 6

Miller, S.R., \& Parkhe, A. (1998). Patterns in the Expansion of U. S. Banks' Foreign Operations. Journal of International Business Studies, 29(2): 359- 390. 
Ye, X. (2006). The Empirical Research of the Influence the Entrance of Foreign Banks on the Efficiency of Chinese Banking Industry. Research on Financial and Economic Issues, 2

Xue, H. (2011). Analy sis on the Motives that Foreign Banks Enter into China. Financial Theory and Practice. 1

Zesheng, M., \& Lei Y. (2005). Customer Following and Foreign Bank Entry: Chinese Evidence and Policy Implication. Journal of Henan College of Financial Management Cadres, 23(6)

Zhu, X., \& Xu, G. (2007). Analy sis on the Motives that Foreign Banks Enter into China Zhejiang Finance, 11 